Article

\title{
Reasons and Consequences of Overtourism in Contemporary Cities-Knowledge Gaps and Future Research
}

\author{
Michał Żemła \\ Department of Tourism and Regional Studies, Pedagogical University in Cracow, 30-084 Cracow, Poland; \\ michal.zemla@up.krakow.pl
}

Received: 3 December 2019; Accepted: 23 February 2020; Published: 26 February 2020

\begin{abstract}
Even though overtourism became the object of extensive scientific research only three years ago, different definitions and approaches to the issue can be seen. However, it is still in the initial phase of research, and there are numerous gaps in our knowledge of the reasons and solutions to this issue. The main aim of the paper is to summarize different approaches and points of view on the overtourism issue. This includes searching for reasons of tension between tourists and visitors in particular destinations. They are presented partially in tourism literature but also in the literature dealing with urban studies, sustainable development and other areas. This aim was achieved through a literature review and the deduction method. The paper identifies several different factors that stimulate overtourism. Some of them are acknowledged in most publications. They are a growing number of tourists, new solutions in the information technologies (IT) business and the availability of cheap flights. Other factors such as management mistakes in particular destinations are underlined from time to time. Finally, some factors are expressed very rarely. They are the growing popularity of city tourism and the shift from 3S (sea, sun and sand) to 3E (education, experience, entertainment) tourism. Identification and general overview of those factors is intended to be an important contribution to the contemporary scientific knowledge on overtourism. The analysis of the factors recognized allowed to point out significant weaknesses of our contemporary knowledge on overtourism. A radical shift of the approach to the governance of cities as tourism destinations, as well as filling theoretical gaps and creating effective tools to manage tourism development in cities are postulated. Several directions of the future research are presented in the conclusions of the paper. Some practical recommendations for decision-makers in particular cities are also included.
\end{abstract}

Keywords: overtourism; tourism-phobia; tourism in cities; tourist gentrification; impact of tourism; experience economy

\section{Introduction}

Negative consequences of tourism development were acknowledged and researched for many years [1], including issues of overcrowding, carrying capacities [2,3] and guests-residents relationships or community antagonism [4]. That is why the term "overtourism" might be perceived as old wine in a new bottle [5]. According to Capocchi et al. [6] p. 10, what is new is mainly the level of awareness of the possibly damaging effects of the continual quantitative growth of mass tourism. Phi [1] added that the current overtourism debate continues many of the issues on tourism development that were undertaken previously, yet, now, they take place in a much wider range of destinations, and they are much more complex, which is a guarantee that they will be explored further [7]. However, it is often justified to perceive "overtourism" as a term that enriches our terminology and our knowledge about tourism development, since it appeared as a result of changed conditions of contemporary 
tourism development and it is intended to illustrate the process typical for the second decade of the 21 st century $[1,5]$. The negative impact of tourism development has recently been associated with terms such as anti-tourism movements, tourism-phobia, tourist-phobia and overcrowding [7] p. 25. Higgins-Desbiolles et al. [8] p. 16 described the conflicts represented by overtourism as a wake-up call as tourism should be reclaimed from an industry that has defined it as a business sector to accumulate their profit, to a human endeavor based on the rights and interests of local communities in welcoming tourists. While causing reductions in the quality of service of a tourist destination and rejection by the local population, overtourism spoils the positive economic and social results produced by the tourism sector [9]. In numerous popular tourist destinations where the harmful effects of overtourism occurred, any previous consensus on the desirability of continuous quantitative tourism growth for the sake of maximizing the economic benefits of tourism, without fully considering the side effects that can be destructive to the social, cultural and ecological environments, has come under intense pressure from the civil society and local populations.

The main aim of the paper is to summarize different approaches and points of view on the overtourism issue, including searching for reasons for tension between tourists and visitors in particular destinations. They are presented partially in tourism literature but also in the literature dealing with urban studies, sustainable development and other areas. This aim was achieved through a literature review and the deduction method. As a result, by summing up pieces of information already presented but in a very scattered way in the contemporary literature, it was possible to present two different approaches to overtourism as well as strengths and weaknesses of the contemporary knowledge on this issue. Referencing many different scientific sources enabled capturing of few factors possibly supporting overtourism and tourism-phobia that were not analyzed in most of the contemporary publications. Those factors are mainly connected with the way tourism develops in particular cities. It was assumed that in the case of contemporary cities, tourism development involves a bigger number of inhabitants with much different attitudes and expectations than in traditional tourism resorts. Those inhabitants are confronted with tourists' behavior that might be evolving quickly, but often does not consider local society as more than a group of people delivering services for visitors. Growing awareness and education of tourists in many cases may not help this situation as those aware tourists in their search for authentic experiences often disrupt local people's everyday life. The most important scientific output of the paper is connected with significant gaps in the scientific knowledge which were identified. Those gaps are to be perceived as the most urgent directions for future research within the field. Additionally, some practical recommendations are offered.

The paper is organized as follows: in the first part of the paper, the notion of overtourism and different approaches to the issue are deliberated. In the next parts, potential reasons of overtourism are presented starting from those that are acknowledged in most of the publications, such as growing number of tourists or new solutions in IT business, through those that are underlined from time to time, such as management mistakes in particular destinations, and finishing with those that are expressed very rarely, such as growing popularity of city tourism and the shift from $3 \mathrm{~S}$ to $3 \mathrm{E}$ tourism. The paper ends with conclusions and limitations.

\section{Overtourism-In Search for a Definition}

Even though overtourism is a new phenomenon and a new subject of scientific research, there are several definitions presented thus far in the literature. Most authors agree that it is tough to present a commonly accepted definition of overtourism. Koens et al. [10] suggest that the term overtourism largely arose from media discourses without a solid theoretical foundation. This new concept can be considered "blurred" because it is not well defined, it lacks clarity and it is very difficult to make it operational [6] p. 8. That is why overtourism remains open to multiple interpretations [10] p. 1. Furthermore, the term overtourism does not describe a single phenomenon but a multitude of phenomena that converge and overlap expressing a new trend worth being analyzed [6] p. 15. Table 1 presents some of the definitions of overtourism presented in the literature. It is evident from this table 
that most of the definitions link overtourism to congestion and failing infrastructures and increased resistance toward tourism and a protest against it among marginalized and displaced inhabitants.

Table 1. Definitions of overtourism presented in the literature.

\begin{tabular}{|c|c|c|}
\hline Source & Definition & Factors Defining Overtourism \\
\hline UNWTO [11], p. 4 & $\begin{array}{l}\text { A situation in which the impact of tourism on a destination, } \\
\text { or parts thereof, excessively influences the perceived quality } \\
\text { of life of citizens and/or visitors in a negative way. }\end{array}$ & $\begin{array}{l}\text { Impacts, harm in citizens' quality } \\
\text { of life }\end{array}$ \\
\hline Peeters et al. [12] p. 11 & $\begin{array}{l}\text { Overtourism describes the situation in which the impact of } \\
\text { tourism, at certain times and in certain locations, exceeds } \\
\text { physical, ecological, social, economic, psychological and/or } \\
\text { political capacity thresholds. }\end{array}$ & Impacts, crossing capacities \\
\hline Higgins-Desbiolles et al. [8] p. 6 & $\begin{array}{c}\text { Overtourism describes a situation in which a tourism } \\
\text { destination exceeds its carrying capacity-in physical and/or } \\
\text { psychological terms. }\end{array}$ & Exceeding capacities \\
\hline Goodwin [13] p. 1 & $\begin{array}{c}\text { Overtourism is about destinations where hosts or guests, } \\
\text { locals or visitors, feel that there are too many visitors and } \\
\text { that the quality of life in the area or the quality of the } \\
\text { experience has deteriorated unacceptably. }\end{array}$ & $\begin{array}{l}\text { Overcrowding, harm in citizens' } \\
\text { quality of life, harm in } \\
\text { tourists' experiences }\end{array}$ \\
\hline Butler [14] p. 635 & $\begin{array}{c}\text { Overtourism represents a situation in which some numbers } \\
\text { of visitors overload the services and facilities available and } \\
\text { also become a serious inconvenience for permanent } \\
\text { residents of these locations. }\end{array}$ & $\begin{array}{l}\text { Overcrowding, harm in citizens' } \\
\text { quality of life }\end{array}$ \\
\hline Milano et al. [7] p. 354 & $\begin{array}{c}\text { The excessive growth of visitors leading to overcrowding in } \\
\text { areas where residents suffer the consequences of temporary } \\
\text { and seasonal tourism peaks, which have caused permanent } \\
\text { changes to their lifestyles, denied access to amenities and } \\
\text { damaged their general well-being. }\end{array}$ & $\begin{array}{l}\text { Overcrowding, harm in citizens' } \\
\text { quality of life }\end{array}$ \\
\hline $\begin{array}{c}\text { Perkumienè, } \\
\text { Pranskūnienè [5] p. } 2138\end{array}$ & $\begin{array}{l}\text { Overtourism is characterized by an excessive number of } \\
\text { visitors, which affects the quality of the region. }\end{array}$ & $\begin{array}{l}\text { Overcrowding, harm in citizens' } \\
\text { quality of life }\end{array}$ \\
\hline
\end{tabular}

Two attitudes towards overtourism might be found in the literature. (Table 2) The first attitude, the wide approach, perceives overtourism as a phenomenon that can be seen in many different places. Sometimes this is stated explicitly, like in Peeters et al. [12] p. 16, who stated that the most vulnerable destinations are not necessarily cities, but rather coastal, islands and rural heritage sites. In other publications, this approach can be seen by a selection of places where overtourism is analyzed $[12,15,17]$. The second approach relates overtourism entirely to cities $[1,5,10,18,19]$. This paper follows the second point of view presented as it is concentrated on the reasons and consequences of overtourism typical for cities. In the urban context, overtourism means not only the growing numbers of visitors together with the growing problems it causes, but it additionally involves new phenomena such as tourism-phobia.

Table 2. Two approaches to overtourism.

\begin{tabular}{|c|c|c|c|c|c|}
\hline \multicolumn{3}{|c|}{$\begin{array}{c}\text { Wide Approach-Overtourism might be Observable in All Kinds } \\
\text { of Destinations }\end{array}$} & \multicolumn{3}{|c|}{ Narrow Approach-Overtourism is Typical for Cities } \\
\hline Publications & Selection of cases & $\begin{array}{l}\text { Direct support of the } \\
\text { approach }\end{array}$ & Publications & $\begin{array}{l}\text { Selection of } \\
\text { cases }\end{array}$ & Direct support of the approach \\
\hline Peeters et al. [12] & $\begin{array}{l}\text { Different destinations } \\
\text { across Europe } \\
\text { including rural, } \\
\text { mountain and other } \\
\text { nature-based regions }\end{array}$ & $\begin{array}{c}\text { The most vulnerable } \\
\text { destinations are not } \\
\text { necessarily cities, but } \\
\text { rather coastal, islands } \\
\text { and rural heritage sites } \\
\text { [p. 16] }\end{array}$ & Milano [15] & $\begin{array}{l}\text { Venice, Berlin, } \\
\text { Barcelona }\end{array}$ & $\begin{array}{l}\text { Among the effects of overtourism } \\
\text { congestion of public spaces in city } \\
\text { centers and the rise in housing } \\
\text { prices are mentioned [p. 7] }\end{array}$ \\
\hline Dodds \& Butler [16] & $\begin{array}{l}\text { Cities (Barcelona), } \\
\text { countries (Thailand), } \\
\text { islands (Boracay) }\end{array}$ & & $\begin{array}{l}\text { Koens et al. } \\
\text { [10] }\end{array}$ & $\begin{array}{l}13 \text { European } \\
\text { cities }\end{array}$ & $\begin{array}{l}\text { The whole paper concentrates } \\
\text { on cities }\end{array}$ \\
\hline \multirow[t]{3}{*}{ Stanchev [17] } & $\begin{array}{l}\text { Cities (Prague, } \\
\text { Dubrovnik) and } \\
\text { islands (Santorini, } \\
\text { Majorca) }\end{array}$ & & $\begin{array}{l}\text { Capocchi et al. } \\
{[6]}\end{array}$ & Venice & $\begin{array}{l}\text { In this context, the term } \\
\text { "overtourism" has begun to be used in } \\
\text { the recent literature with particular } \\
\text { regard to models of tourism } \\
\text { development, some city destinations, } \\
\text { and issues of sustainability [p. 1] }\end{array}$ \\
\hline & & & Phi [1] & & $\begin{array}{l}\text { Modern overtourism essentially takes } \\
\text { place in the urban areas [p. 3] }\end{array}$ \\
\hline & & & $\begin{array}{l}\text { Namberger } \\
\text { et al. [18] }\end{array}$ & Munich & $\begin{array}{c}\text { City destinations are particularly } \\
\text { interesting study areas for } \\
\text { overtourism }[\mathrm{p} .453]\end{array}$ \\
\hline
\end{tabular}


According to Peeters et al. [12] p. 21, by its very nature, the overtourism phenomenon is associated with high numbers of tourists, the type and time frame of their visits and a destination's carrying capacity. Thus, overtourism may appear when the number of tourists in a particular place is extremely high. However, overtourism is not just the same as the phenomenon of overcrowding, which is commonly known and has been researched for many years [15]. Too many tourists in a particular place is not enough to call it overtourism. According to the definition by Peeters et al. [12], the key factor is the impact of tourism. However, destinations with tourism development that approach or exceed their ecological capacities were identified and researched plenty of times, thus, this problem is not to be perceived as a new phenomenon defining overtourism. In fact, what is new (or most likely forgotten in tourism research for the last few decades) in the definition by Peeters et al. [12] is a social capacity [18].

At the very beginning of the research on tourism impacts, it is possible to find many works [20-22] on the social impact of mass tourism under the heading of alternative tourism, which was one of the very important topics of tourism studies between the 1960s and the 1980s. Mass tourism, which was growing fast at that time, was perceived negatively, as local societies in particular destinations were excluded from economic benefits and were bearing the social and cultural costs of its development. Additionally, tourists were consuming poor, culturally inauthentic products [23,24]. Unfortunately, it appeared that small scale alternative tourism cannot be a proper solution to solve the global problem of mass tourism. The outcome of the alternative studies stream was a bit forgotten when sustainable tourism development studies took the lead with the clearly underlined ecological impact of tourism and the need to balance economic, social and ecological pillars of that development. Among those three, the social impact of tourism is the most difficult one to be researched and the most ambiguous one. It is commonly agreed that the economic pillar of tourism development is mainly about benefits; the ecological one is mainly about costs. It is easy to identify the many cost and benefits of tourism development of a social nature, and the balance of the social costs and benefits can be very different in different places and it can change with time. Thus, it is not surprising that several scientific and practical studies on sustainable tourism development were concentrated on balancing the economic benefits and the ecological costs.

On the contrary, many studies in over-visited city destinations are focused on the social carrying capacity [18] p. 452. The significance of the negative social impact is evident in the most commonly reported examples of overtourism. The very common part of those examples is the resistance of citizens of particular cities against tourism and tourists, which is manifested in differentiated ways [18]. Higgins-Desbiolles et al. [8] p. 6 stated that overtourism indicates that local communities are becoming increasingly hostile to forms of tourism that are imposed on them and diminish their quality of life. A popular term used to present this inhabitants' negative perception of how tourism development impacts their lives is "tourist phobia." The term was used for the first time in 2008 to explain a mixture of repudiation, mistrust and contempt of tourists [16] p. 25. Later, a similar concept, tourism-phobia, has been deliberated together with overtourism as a direct result of the accelerating evolution of unsustainable mass tourism practices [7]. Examples of tourist-phobia were already identified in many cities such as Barcelona [16,25], Venice [12,26,27] or Berlin [16].

To understand the nature of overtourism, its causes and consequences, it is necessary to understand why citizens of particular cities started to perceive tourism as a factor that has a negative impact on their quality of life [28]. The answer to this question is complex and includes changes of quantitative and qualitative nature and factors coming from the outside of the tourism industry as well as those from the inside, including those who were and still are at least partially dependent on tourism stakeholders' actions. The widely recognized factor, which is independent of the tourism industry and tourism academia actions and which is of typical quantitative nature, is the growth of tourism. Fast-growing numbers of tourists, which is an objective fact confirmed in statistics (such as those conducted by United Nations World Tourism Organisation - UNWTO), is partially supported by marketing activities of the tourism companies and public bodies, but it is mainly influenced by trends in the global economy, politics, technology and demography. However, overtourism should not be perceived as merely 
a too big number of tourists. To understand the dramatic increase of the perception of hosts that tourism may be a disadvantage for their lives, an additional switch in tourist behavior and preferences is to be considered. That switch is much more difficult to be captured and measured than just the growing number of tourists, and as such, it is much more ambiguous and controversial. What is also of great importance is the fact that, at least partially, tourism policies following models proposed by the academia are responsible for that switch.

\section{Well-Recognized Sources of Overtourism}

UNWTO [29] reported that the number of international tourism arrivals is steadily growing. For decades, global tourism has been rapidly and constantly growing. For the first time, the number of international tourist arrivals has exceeded 1 billion in 2012 and is expected to almost double by 2030 [11]. This is coupled with an even higher growth of domestic tourism activities and other forms of tourism-related mobilities $[1,30]$. There are numerous reasons for this. Currently, growing tourism activity among Chinese society supported by political enhancement is often pointed to as one of the important and characteristic factors for current times [28,29]. This tremendous growth of tourist numbers in recent years, along with tourists' tendency to travel to popular destinations during the same periods, is often pointed to as the leading cause of overtourism [1] p. 2.

It can be seen that many authors who present their concepts of reasons for overtourism are largely focused on factors that make contemporary people travel more often. This can be found in the book by Butler and Dodds [17] p. 6. These authors provide a list of 10 enablers of overtourism, which are: (1) Greater numbers of tourism; (2) Travel has become more affordable; (3) New groups of tourists; (4) Dominance of the growth-focused mindset; (5) Short-term focus; (6) Competition for space, amenities and services; (7) Wider access to media and information; (8) Destinations lack control over tourists numbers; (9) Imbalance of power among stakeholders; (10) Tourism stakeholders are fragmented and at odds. The first enabler is about the growing number of tourists, the next two give some reasons why this is so, and the others are focused on the reasons why particular destinations fail to cope with this huge number of visitors.

Another argument showing how strongly overtourism is perceived as growth-driven can be found in actions undertaken in some destinations as well as in suggestions presented in the literature. They both often search for solutions for overtourism in concepts such as degrowth [8] or demarketing [25].

The list for reasons of overtourism and for the growing numbers of tourists can be extended. Many authors such as Phi [1] and Goodwin [13] referred to the falling cost of air travel and low-cost carrier companies' growth, the expansion of sharing platforms, seasonality and the concentration of tourists in certain areas. Alonso-Almeida et al. [9] underlined the role of social media in establishing overtourism, as they raise tourism demand and direct it to particular destinations. Additionally, Phi [1] points to the complex nature of the local/global tourism supply-chain, and the exceeding efforts that the destinations put into marketing actions. Especially the last sentence is important, as it means that this growing number of tourists that are blamed for overtourism has been stimulated for many years by tourism promotion and many destinations spent significant amounts of money on "inviting" overtourism.

Those expenses include both promotional actions and a development of tourism products. Indices that could prove that they were effective were necessary to justify incurring these expenses. Due to numerous reasons [12,13], the number of visitors/tourists was the index that was used most often. Compared with other indices that might be used here, it is relatively easy to be measured and objective. As it was used in international statistics (such as UNWTO), it gave a perfect opportunity to compare own achievements with competitors. However, concentration on that single index made decision-makers lose sight of other indices that present real benefits and costs of tourism development. A tacit assumption that the more tourists, the better effect, was made without an in-depth analysis of how a growing number of tourists enhances their expenditures, supports job creation, reduces unemployment, etc. As a result, the performance of tourism marketing and management organizations is measured in international tourist arrivals rather than the yield or the spread of tourism to bring 
benefits for areas that need more urgently expenditures made by visitors. [13] p.6. Based on the analysis of over 30 examples of places with overtourism in Europe, Peeters et al. [12] p. 18 stated that most destinations are managed based on a growth-paradigm, with the main appreciation for the growth of visitors' numbers, without considering carrying capacity and other policy goals. Cheer et al. [28] even referred to plenty of narratives that treat the growth of tourism as a Holy Grail. That way of thinking was not perceived as a mistake for many years, neither by practitioners nor in the academic works. For example, the UNWTO is frequently cited as the key promoter of the need for constant tourism growth, despite the problem of overtourism [1]. Goodwin [13] p. 3 presented several examples of tourism management textbooks that were published about 20 years ago and supported that kind of thinking. Even the structure of many of those textbooks, with many chapters devoted to marketing (which means attracting visitors) and just a few chapters on making real economic benefits and minimizing economic, social and ecological costs, makes Goodwin's point of view rational. Milano et al. [7] p. 335 called for models and measures of tourism success in global tourism policy that would mirror a shift from a focus on destination development and stimulation of growth in visitation, to more accurate forecasting of what the implication of excessive tourism numbers might mean for a destination.

Growth-centric strategies of tourism development in particular cities led to another tragic mistake, which was opening doors of coastal cities for cruise tourism too wide. For many years, Venice was presented as a "perfect" example of a destructive impact of overdeveloped cruise tourism on the city's sustainable development, including influence on environment, citizens and tourists $[6,16,26,27,31]$. After the tremendous success of Game of Thrones being shot partly in Dubrovnik, this city is perceived as even more strongly "infected" by overtourism and, in particular, by cruise tourism [6]. Panayiotopoulos and Pisano [32] indicated the "overtourism dystopia" related to the paradox of tourism that risks the destruction of what tourists come to see. In both cases, it should not be perceived that the overtourism problems of both cities are caused by the cruise tourism only, but both cities suffer because of the huge number of tourists traveling there by planes, coaches, cars or trains, and there is another huge stream of tourists traveling there by the sea. Even more discouraging is the fact that this huge stream of tourists does not bring too many benefits for the local economies as they arrive to their destinations with their own accommodation and often also with gastronomy on-board. However, the problem is so obvious that in many places, local authorities have taken different measures to deal with it. For example, in Dubrovnik, policy responses have included attempts to limit the number of tourists admitted to the city and to restrict the capacity of cruise ships permitted to call at the city's port [6] p. 12. The transport minister of Italy responded to Venetians' anti-tourism protests by announcing that Venice will restrict the Giudecca Canal's access to all the ships of more than 55,000 tons of weight. These cruise ships will take another route and will dock at the industrial port of Marghera [15] p. 20.

However, many authors turned our attention to factors not directly connected with numbers. The most commonly unaccepted tourists' behavior has been pointed out $[1,9,13]$. Seraphin et al. [27] noted that the environmental sustainability of destinations might be permanently jeopardized and that the tourists are impacting negatively on the quality of life of the locals and reducing the positive contribution of tourists to local legal businesses. Overtourism has also been linked to the Tragedy of the Commons, as tourism activities often rely on and heavily exploit public resources $[1,13,33]$. Additionally, Cheer et al. [28] stated that overtourism appears for a variety of reasons, which are shaped by a number of supply-side destination drivers, demand-side factors and a global supply chain. The last two are difficult for destinations' management to influence. Finally, it is clear then that particular reasons for the appearance of overtourism in a destination might differ significantly between particular places.

\section{Shifting Tourists' Interests from Resorts to Cities}

According to Phi [1] and Koens et al. [10], overtourism is not only related to the objective increase in the number of tourists, but also that the subjective factors play an important role. They usually 
involve inhabitants' perceptions that tourism influences their lives negatively, as they can be impacted by a number of factors, such as tourists' behavior, historical exposure to visitors and differing levels of community resilience. Indeed, it is hard to justify these dramatic and sudden tourist-phobia attitudes among citizens of many cities by growing numbers of tourists only. Tourism growth can be observed on a permanent level without dramatic breakthroughs lately [29]. It is expected then that at least some symptoms of anti-tourism movements should have been observable for many years. An important hint to interpreting the reasons for overtourism is to be found in the fact that thus far tourist-phobia was reported almost only in smaller or bigger cities $[6,13,16]$, while in traditional tourist resorts, it was reported very rarely, if ever. This should be compared with a visible shift in tourism statistics, which shows that big cities are becoming more and more popular and fashionable destinations [18]. Hitherto, the research dealing with tourism impact tends to focus on overcrowding in the context of national parks and protected areas. However, as Phi [1] p. 3 stated, modern overtourism essentially takes place in the urban areas. A similar conclusion can also be found in other publications $[5,10,18,19]$.

The strong increase in demand for city tourism has several causes [18] p. 453: people are taking shorter holidays but travel more often [34], low-cost carriers enable people to reach cities for affordable prices [35] and cities increase their attractiveness by organizing various events [36] as well as becoming more and more popular as a location for shopping, culture and sightseeing [37].

Cities differ significantly from destinations of other kinds. They provide visitors with a range of multifunctional, complex and multiuser environments. They are able to host increasing numbers of domestic and international leisure tourists simultaneously, but also business tourists and people visiting friends and relatives [10] p. 2. The fact that cities are usually equipped with good infrastructure facilities and host a dynamic and diverse population nowadays may suggest that they will deal with the growing tourist number better than other destinations. Indeed, until recently, tourism was seen as one of the most sustainable economic growth strategies for cities. Especially after the last global economic crisis, it was perceived as a significant driver for economic recovery or growth [10] p. 2.

The fast growth of tourists' interest in visiting cities $[38,39]$ is among the most underestimated tendencies in contemporary tourism, and significant differences between typical resort destinations and cities were missed by tourism companies, tourism authorities, tourism academia and, finally, by tourists themselves. Those differences are of great significance as destination's carrying capacity differs between types of destinations such as islands, rural destinations or city destinations [18] p. 453. Participants of mass tourism were used to visiting the destinations that were better and better adjusted to their needs, and that sometimes the destinations (so-called integrated resorts $[40,41]$ ) were even totally designed to satisfy tourists' expectations perfectly. In many seaside or mountain resorts, tourism became a dominant economic function of the place, which became totally economically dependent on tourists' arrivals and expenditures [42]. Additionally, especially during the peaks of the season, the number of tourists could be several times bigger than the number of inhabitants. In such conditions, the basis of the theory and practice of tourism organization and management were developed. Economic dependency was often so strong that not only local authorities but also most citizens were aware that their economic prosperity depends on tourism and the relationship between more tourists, and even greater prosperity was easy to accept [43]. Fierce competition between destinations forced particular destinations as a whole, but also particular stakeholders, including inhabitants, to do their best to make visitors satisfied. More and more management, or, later on, governance theories were established to make a success of a destination more probable [44-46]. They appeared to be efficient in building tourism resorts competitiveness; however, when we consider a city as a tourism destination, every single condition presented above has to be adjusted [47]. Apart from an evident difference between proportions of a number of inhabitants and a number of tourists, the most important fact is that usually in cities, neither a city as a whole nor most citizens, perceive their economic prosperity as dependent on tourism. In most cities, tourism may play only a supporting role in their economies, while in other cities it may even be one of the important economic functions of the city, but hardly ever is the most important one. The inhabitants who do not see any economic benefits (and also benefits of other 
kinds) are not willing to limit their needs and adjust their way of living to satisfy the visitors' needs. This makes a huge difference between the inhabitants of resorts and cities.

As was stated earlier, that difference was missed by tourists, tourism practitioners and researchers. Theories that turned out to be effective in making tourist resorts competitive were now used directly (without being modified) in the pursuit to make cities competitive destinations [13]. Sooner or later, such attempts had to fail, leading to dissatisfaction of citizens and/or of tourists. For both of those groups, visitors-inhabitants encounters are new in their form and somehow uncomfortable. For most citizens, tourism developing in their neighborhood is a new phenomenon [48]. The perception of the lowering quality of life is not only a result of what burden tourism is but also of factors that were not influencing that quality earlier on [49]. Tourists are used to the fact that they are customers and are treated as precious clients by everyone in their destinations. Tourists pay for their holidays and expect to get the perfect product and do not want to limit and adjust their behavior to local requirements. On the contrary, they expect that the local requirements should rather be changed or adjusted for tourists' satisfaction.

It is difficult to understand citizens' resistance to tourism development without understanding the nature of the impact of tourism on their lives [49]. The most evident effect, most frequently described in many publications [5,18], is congestion: congestion of pedestrian zones, lines in shops, a crowd in means of public communications, etc. Another factor that is often presented in the literature is improper behavior of tourists $[1,9,13]$. The way the tourists behave, speak or wear their clothes may abuse local traditions. A big number of loud and sometimes drunk tourists also lowers the sense of security. Finally, many citizens notice that some parts of the cities, most frequently the city centers, change into a big party zone.

However, the problems presented above are not new. They have been present for many years as cities have been destinations for tourists for decades. Nowadays, together with a surging increase in visitation to cities, those problems also seemed to be more severe. Still, the contemporary development of tourism in cities has also brought problems that have been almost absent previously [48]. Those problems are often identified in the literature related to the sharing economy but should not be referred only to the development of this phenomenon. Many authors [49-56] agree that the extremely rapid development of sharing economy platforms such as Airbnb influences cities' real estate market severely. The essence of that impact is related to a big increase in the demand for houses and apartments created by prospective runners of the P2P (peer-to-peer) services. This increase caused several consequences that can be observed in different places and on a different scale [57]. In many places, short-term tourism rental appeared to be more profitable for residents than renting. As a result, in order to maximize their profits, investors, both big players and small local ones, have been attracted to the P2P accommodation market, where small investors with as little as one apartment to rent can access the global marketplace. Horn and Merante [56] suggested that home sharing is a factor that increases rental prices by decreasing the supply of units available to potential residents. As a result, for five years, the rental market in Paris, for example, has lost about 20,000 homes. In some districts (especially in the center and in the west of Paris), tourism furnished apartments can represent up to $20 \%$ of the total rental offer [57]. Similar findings were presented by Wachsmuth and Weisler [58], who identified neighborhoods in New York where the housing markets have already been significantly impacted by short-term rentals at the cost of long-term rental housing, which are increasingly under the threat of Airbnb-induced gentrification. In many places, the development of the sharing economy has also coincided with housing shortages and affordability issues. The reasons for those housing problems are diverse, complex and historically embedded in, for example, the evolution of national and regional housing policies, infrastructure and investment policies. Among important examples of these external factors that make the housing problems more difficult, increased EU mobility and more relaxed rules for property investment can be pointed out. Those factors have contributed to a real estate boom in coastal areas of Spain, including Barcelona [59]. The factors presented, together with the demand increased by investors who buy properties for short-term tourism rental were the reason why two negative phenomena appeared. The 
natural reaction of the market to the increasing demand was also a cause of increasing prices of real estate, both to buy and to rent. Unsubstantiated reports suggest that the cost of housing rental in Berlin grew as much as 56\% between 2009 and 2014 [60]. The effect was also the growing shortage of properties available on the real estate market in particular cities. As a consequence, affordability issues also arose. Housing affordability issues made financially challenged residents seek additional income through renting, which resulted in an even greater housing shortage. These sorts of effects have, in turn, put considerable pressure on city governments to develop regulatory frameworks to cope with a process that was hardly ever mentioned in public discourse only a few years ago [52].

Apart from affordability and shortages problems, the development of tourism sharing platforms should contribute to citizens by bringing them additional income, thus improving their quality of life [56]. This process phenomenon undoubtedly takes place [61]; however, recently, a new process, which is clearly a limitation to positive economic effects for ordinary urban residents, can also be seen. This process is related to purchasing attractively located real estates mentioned above and is regarded as a capital investment, which is additionally supposed to pay off by bringing revenues by selling accommodation through sharing economy platforms. In many cities, apartment networks come into being; a new business model of a hotel enterprise was even offered (integrated hotel), which consisted in the operation of a central reception for apartments distributed in different buildings of one city [62]. According to the research by Horn and Merante [56] conducted in Boston, only 18\% of hosts had multiple properties listed simultaneously in Boston. Their properties represented almost half of those listed on Airbnb (46\%), which suggested that a large part of Airbnb's properties in the city are leased by commercial operators. A similar situation was detected in New York City by Wegmann and Jiao [51]. These new trends are the reason why real estate renting revenues from sharing economy platforms are not distributed to a wide range of residents but are transferred to a small group of investors, who sometimes are from the outside [63]. As mentioned earlier, this process is also the reason why the operation of the local real estate market is significantly disturbed, and it becomes a matter of concern for the local regulatory authority.

Development of tourism in cities supported by accommodation sharing economy platforms brings economic benefits, but they are distributed unequally, and a significant part of them leaks outside to external owners of apartments. Thus, it is easy to understand why many citizens do not benefit from that development. Still, apart from economic costs related to apartment rents and prices, they also have to suffer from other troubles. This is because tourism spreads to districts that were previously used only for residents. Online home-sharing platforms for visitor accommodation blur the traditional boundaries between residential and tourist areas [64]. Providing accommodation in a district that has not been visited by tourists has become an attractive option for earning money for owners of flats and houses, and it attracted numerous guests lured by Airbnb's slogan 'live like a local' [13]. It soon turned out that the city inhabitants who were able to bypass the tourist traffic by passing by the historic city centers where tourist traffic was focused, currently cannot do this, as they meet numerous tourists using accommodation services in facilities immediately next to them [65]. The most important fields of conflicts are the shortage of available living space, the increase in rents and the problem of constantly changing neighbors. Additionally, the behavior of Airbnb users is seen as problematic [18] p. 463. At the same time, those who live next to the historic sites often complain about the lack of an 'ordinary neighborhood,' because all apartments or houses in the neighborhood are rented to tourists. As a result, they feel as if tourists continuously stayed in a tourist town, while the groups of neighboring tourists constantly changed. This led to Gürsoy's [19] p. 431 statement that everyday life is the base where tourism-phobia is taking root.

Oftentimes, development of tourism in cities is blamed for supporting gentrification processes [48,54,58,66,67]. According to Cocola-Gant [66], gentrification caused by tourism is increasingly affecting a number of places around the world. In this process, the original residents of traditional neighborhoods are economically "expelled" to the urban periphery as a result of the increase in rental prices in their neighborhoods [54]. Although some scholars have noted that tourism threatens 
the 'stay-put' right of existing populations [66-69], a conceptualization of how this phenomenon occurs has not been fully considered [66]. Gentrification is not a new phenomenon-in the United States, it is usually perceived to have begun as early as in the 1950s [67]. Still, the previous waves of this process were not connected directly with tourism; only the latest, third wave of gentrification includes tourism gentrification [67].

All the facts presented above made cities' representatives search for solutions for this situation [26]. There were numerous attempts to regulate the real estate market to make it more difficult to turn residential properties into commercial ones [57]. Additionally, congestion was a concern for authorities in many places $[13,57]$. However, old "resort-like" thinking can be very often seen in their actions. For example, Copenhagen has adopted an aggressive redistribution strategy spreading tourism across the city, "declaring the end of tourism as we know it" [13] p. 4. While commenting this generally accepted step, Goodwin [13] p. 4 wondered whether it will generate protests by residents. Stanchev [15] p. 19 gave other examples of similar actions from Prague, Amsterdam and Venice. The aim of such campaigns is to motivate the tourists to explore attractions that differ from the popular ones, at the same time suggesting less congested attractions and "local experiences" and encouraging tourists to spread out more by introducing tourists to less frequently visited parts of the city [15] p. 19. Both sides, residents and visitors, suffer from congestion in the most attractive parts of cities; however, it seems that mainly visitors may benefit from the results of successful redistribution. Additionally, the tourism industry should appreciate the growing capacity to host even more tourists in the city. However, from the point of view of citizens, the results of such a redistribution most likely will make the situation even worse. This is so because it supports invading increasingly more residential parts of cities by tourism, and all problems presented above with the real estate market and lack of regular neighborhood will only be intensified.

Cities most often related to tourism-phobia are often metropolises where the old city is not understood in a traditional way, such as Barcelona (according to the research by Phi [1], Barcelona is by far the most often described city in global news media in the context of overtourism), Amsterdam, Paris or Berlin in Europe [13]. On the contrary, cities such as Budapest, Prague or Cracow are also often involved in overtourism, but more in terms of congestion, and just a few manifestations of reluctance between tourists and citizens are noted there [17,70-73]. Old cities that are parts of those cities are totally dominated by tourists and play the role of a tourist ghetto in those cities [17]. Additionally, most of the must-see attractions of the cities are located there. As a result, the boundary between the tourism zones and the residential ones is more evident. Citizens often treat old cities as lost [18] p. 462, but they may expect a relatively low impact of tourism in their places of living and working. In Berlin, Amsterdam or Barcelona, the boundaries between residential and tourism parts of the cities are blurred, and citizens often spend their time in the same places as tourists do. This causes citizens to be exposed to even more to congestion and compete with tourists even more severely for the same attractions and places; finally, it leads to conflicts and reluctance $[18,49]$. That is why, to protect citizens, local authorities should rather implement dynamic zoning strategies and aim to separate tourists and citizens [17] than redistribute tourism to more and more residential parts, which make the processes of gentrification even stronger. Such actions have been conducted for many years, for example in Bruges and Dublin [12]. This conclusion seems to be neglected thus far, both in the most of cities authorities' actions and in the scientific literature. However, one should remember that there are no two identical cities, and the problems and reasons for overtourism are diverse [69]; moreover, effective solutions in one place are not going to work in another. That is why it is also possible to imagine a city in which redistribution strategy can be effective in satisfying citizens' requirements. Such cities should have attractive parts that are not visited by tourists too often and are located outside the typical residential zones.

Another important reason for the conflict between tourists and citizens in particular cities derives from the nature of assets used by tourists and/or inhabitants. When describing this situation, Goodwin [13] p. 8 referred to overtourism as a classic case of the Tragedy of the Commons. The problem 
in the fact that tourism makes extensive use of common-pool resources in the public realm and takes advantage of, for example, monuments or viewpoints that are free or priced on a non-market basis, which was initially bringing benefit for the residents. The tourism commons are very vulnerable to crowding and degrading by tourism pressure. The industry enjoys free access to public goods, which are very often its core product [13] p. 7. The public realm is free-tourists do not pay for their walks in La Rambla or Champs-Elysees-but repair and maintenance costs have to be covered by local taxpayers [13] p. 5. The public realm is funded through local taxes-the residents pay for public toilets, building maintenance and waste disposal. At the same time, tourism businesses are selling the public realm, but they do not pay anything for the resource they sell. Neither tourists nor inhabitants usually understand the nature of the public realm and pool assets, but both of them demand their comfortable access to those assets. Goodwin [13] seems to accept the citizens' right to be hosts and disposers of the local free assets, and this right is based not only on their localization, but also on paying for their maintenance via the local tax system. The natural consequence of this view is an introduction of some kind of fees paid by tourists and tourism businesses aiming to introduce tourism into financing free attractions, but also possibly limiting the excessive number of tourists and enhancing citizens' opportunity to make use of the famous places of their cities. Regardless of the technical difficulty of this solution, this might be challenged under the intra-generational equity [74,75], one of the most important pillars of sustainable development. The introduction of fees limits the demand and eliminates the poorest tourists from visiting places.

The list of potential negative impacts of tourism on cities and their inhabitants is even extended by Benner [76] p. 2. According to him, the potential threats related to overtourism include gentrification, growing costs of living and housing (not only because of increase of rents but also because of growing prices in local shops also visited by tourists), real estate speculation, deterioration of local residents' identification with the place, loss of a destination's authentic character, significant harm to its cultural or environmental heritage, congestion of transport infrastructures and privatization of spaces that are supposed to be publicly accessible-and hence segregation. Additionally, Milano [16] states the loss of residents' purchasing power and the unbalanced number of locals compared to visitors. However, the extreme pressure of tourism on inhabitants' everyday life, which can be observed, for example, in Venice, involves much more pedestrian factors such as the lack of essential shops for everyday life, which have been replaced by tourist shops and rising prices that lead to the forced exodus of many residents [16].

\section{The Transition of Tourism from $3 S$ to $3 E$}

A few decades ago, mass tourism was criticized not only for its negative impact on destinations, but supporters of alternative tourism, and many other scholars and experts, were pointing out very little benefits for tourists $[20,21,77,78]$. Tourists who spend whole days passively lying on beaches did not get much knowledge about the places they visited and had very little contact with local inhabitants and their tangible and intangible cultural heritage [22]. Almost identical remarks were referred to sightseeing trips that were also very popular at that time and perceived as a form of mass tourism. Such trips were concentrated on "ticking places off a list," maximizing the number of must-see attractions during one trip and, as a consequence, reducing the time spent in particular places as much as possible. The relationships between visitors and their destinations were extremely shallow and concentrated on tangible heritage, while completely omitting people currently living in particular places [20].

However, more and more tourists have become interested in local intangible cultural heritage, such as traditions, food, dress, dances, etc. Their needs were often satisfied with what MacCannel [23,24] described as staged authenticity. These were often artificial shows (but this could also include shops or restaurants dedicated to tourists) produced for tourism purposes that presented the local culture, only in a more or less detailed way. MacCannell $[23,24]$ developed this concept to illustrate the fact that tourists are often provided with experiences or performances that are theatered or orchestrated in order to meet the expectations of tourists. These experiences or performances are usually superficial, 
featuring only the 'front stage' area of a particular culture. Therefore, tourists who seek the 'real' or the 'genuine' in a foreign culture end up with experiences that are staged, which is a restriction for tourists who seek to peek into the 'backstage' area of a community to get a comprehensive understanding of a particular local culture. However, Mohamad et al. [79] argued that although tourists can afford these experiences, they do not have the right to the 'back region' unless communities are willing to show it to them. It should be up to the local communities to decide what they deemed appropriate for the tourists to see and experience [80]. In that sense, staged authenticity events played an important role as a security buffer for inhabitants who did not want to introduce tourists to their everyday life and also for tourists who feel safe in a situation arranged especially for them [80].

In the 1980s, some of the tourism scholars announced a huge shift in the nature of tourism that took place at the time. This shift was later on briefly described as a transition from $3 \mathrm{~S}$ tourism to $3 \mathrm{E}$ tourism, where the three "S"s were symbols of "sea, sun and sand" while the three "E"s were symbols of "education, entertainment and experience (or excitement, or emotions)" [81,82]. This shift was enthusiastically welcomed by the academia and practitioners as a highly favorable trend. Since that time, elements included in 3E have been playing an increasingly larger role [83,84]. Typical trips to coastal resorts are still the leading products of tour-operating companies, but their customers often do not spend the whole time on passive relaxation, sharing their time between beaching, visiting monuments, sporting activities and cultural events.

At the beginning of the 21st century, two new economic theories mirrored the growing importance of tourists' experiences in tourism: experience economy [85] and experience marketing [86-88]. Both of them found tourism among the most important areas of the current economy where customers' experiences play a key role. This role was also noticed by tourism practitioners who started to adjust their products and their marketing activities to underline the special experiences that they can offer. At the end of the second decade of this century, nobody doubts the crucial role of tourists' experiences in different kinds of tourism, including city tourism $[88,89]$. Tourists who search for their experiences have begun to be more and more active, mobile and open for contacts with local inhabitants [49].

All those processes were warmly welcomed by tourism scholars as they are at least partial implementation of postulates of advocates of alternative tourism, however, on a much bigger scale. Still, we should not forget about the negative consequences that also exist. Partially, they are strictly related to city tourism and tourism-phobia that accompanies overtourism in cities. Many contemporary tourists are no longer satisfied with a shallow relationship with a visited city, which is limited to a short stay and concentrated on visiting the most famous monuments [49]. The factor that started to play a very important role in the competition between cities on the tourism market is the ambiance. Traditional city destinations that built their competitive position on the bases of monuments and heritage such as Rome or Paris had to face competition from cities such as Amsterdam, Barcelona, Milan or Berlin. The growing popularity of the so-called city breaks [90-92] made tourists visits in a single city a bit longer, and during their stays, tourists are not concentrated so much on visiting monuments, but rather on having fun, shopping and spending their time nicely. This effect was even strengthened by the Airbnb adverts suggesting tourists will be "living like a local" [13] p. 5. Indeed, spending time in, for example, Barcelona in the way that Barcelonan people do started to be fashionable in the tourism market. The citizens' way of living in Barcelona, Amsterdam or Milan started to be tourism attractions, and many tourists have been visiting those cities for that reason. The problem is that nobody asked citizens if they want their way of living to be a tourism attraction. Unlike cities with more precisely set borders of the old city such as Prague or Cracow, in those cities, it is not possible to keep tourists in a tourist ghetto that is not visited by citizens too often. In fact, inhabitants and visitors compete for the access to exactly the same places that are precious assets for both these groups. As an example, La Rambla in Barcelona can be pointed out. Visitors who try to follow the inhabitants' way of life can be a real burden for the locals [49]. They want to stay overnight in places where citizens live, eat in restaurants for the locals, shop in the same shops, etc. Visitors are searching for 'alternative public spaces,' 'creative urban areas' or 'ethnic precincts.' Wandering 'off the beaten 
track' is considered an important strategy to find these places [49]. They perceive their product as authentic. As a result, citizens may have difficulties to escape from tourism to a "safe shelter," and this strengthens the tourism-phobia attitudes.

Contemporary city tourism seems to be a good example of the implementation of postulates of the tourism literature. Tourists here are active and open for meeting local people, searching for authentic products without being satisfied by staged authenticity. It turned out that the implementation of those postulates produced nightmares for the city's citizens.

\section{Conclusions and Limitations}

\subsection{Discussion}

Overtourism is defined differently in different publications. Usually, the objective facts of the growing number of people traveling worldwide and of the development of the new media and technology solutions, including reservation platforms of sharing economy, low-cost airlines and web 2.0 in tourism, are to be blamed for the appearance of overtourism. In such an approach, overtourism seems to be somehow inevitable. However, in many publications $[1,10,13]$, other factors that support the development of overtourism are stated. The most often mentioned example is consumer behavior, which is changeable and often improper. Another reason for overtourism, which is often highlighted in the literature, is growth-oriented tourism policy $[12,13,28]$ conducted for many years by different public bodies on the national, regional, and local scale. Severe competition between numerous destinations worldwide forced the implementation of aggressive marketing strategies that welcome more and more guests. The use of such strategies was perceived positively by practitioners and in tourism textbooks for many years, as it appeared to be effective in cases of many tourism resorts. Additionally, the local, regional and national governments were not prepared to deal with the negative consequences of overcrowding, as the studies conducted by Peeters et al. [12] did not reveal any evaluation or monitoring programs in any of the destinations studied, making the effectiveness of the measures in the particular place difficult to assess [12] p. 16.

Scientific research on the topic of overtourism, besides its rapidly growing popularity, is still at its initial stage. Contemporary studies include mainly overview papers and case studies with a very little number of empirical research of visitors or citizens' opinions (examples can be here the studies by Namberger et al. [18] conducted in Munich and by Smith et al. [72] conducted in Budapest). Additionally, the theoretical description of the issue is scattered; case studies of cities, as well as of nature-based destinations and traditional resorts, are presented. Additionally, the recapitulation of the scientific knowledge on the possible effects of overtourism needs in-depth studies of previous publications on tourism impact and sustainable tourism, but also of the literature not directly related to researching tourism and dealing with urban studies where problems of gentrification or impact of tourism development on real estate market are presented.

As overtourism is often observable in the urban environment, the presented paper links the reasons and consequences of overtourism with the rapid growth of the popularity of city tourism. Reasons for this shift in tourists' interest are numerous, complex and are mainly similar to the issues linked with the genesis of overtourism-the growing popularity of Airbnb-type reservation platforms, new IT solutions, accessibility of cheap flights and shortening the length of tourism trips. However, neither reasons nor consequences of the growing popularity of city tourism were researched in-depth thus far. The long-term aim of future research should be the establishment of a coherent theory of development of tourism in contemporary cities, taking into account new phenomena such as overtourism, tourist-phobia or wide-scale gentrification. Theories of tourism development created 20 years ago and mainly for tourism resorts' purposes are not appropriate for contemporary cities, and even after upgrading them for contemporary cities, they seem to be insufficient. In fact, tourism development in plenty of contemporary cities realizes many postulates of this theory. the number of visitors is quickly growing, as well as visitors' expenditures, while tourists tend to search for 
authentic experiences and try to follow the way of life of genuine inhabitants. However, realization of those postulates resulted in appearance of new problems such as tourism-phobia instead of bringing positive effects.

\subsection{Future Research and Practical Recommendations}

Changes in contemporary tourism and in contemporary cities are very rapid and results achieved a few years ago might not be relevant to current challenges. That is the reason why a lot of future research of the topic are required. New phenomena, such as overtourism, have not been extensively researched thus far, and well-known phenomena such as tourism gentrification got a new momentum. This mixture of old and new problems creates a tension in many cities, and local authorities urgently search for methods of solving them. This part of the papers is devoted to the presentation of a list of directions of future research that were estimated as the most urgent. However, this list cannot be perceived as complete and closed.

An important issue to be researched is the impact of the growing tourism traffic in cities. Cities differ significantly from destinations of other kinds and, especially, the impact of tourism development here is totally different from that researched for many years in tourism resorts or in nature-based destinations. Still, the nature of this difference needs to be studied. Future research should help to develop tourism policy tailored for cities, which needs to point which exact tools and suggestions presented in contemporary literature on destination management are to be adjusted and how. It was already underlined in the literature that visitors might be perceived by inhabitants of a city as unwanted invaders that do not support citizens' economic prosperity and significantly deteriorate their quality of life due to their improper behavior, congestion, negative impact on the real estate market and gentrification of neighborhoods. In most publications, all those negative impacts were presented without detailed analysis. Future research should then analyze which kind of tourist behavior is perceived by citizens as the most annoying and which one can be accepted. Similarly, the scale of congestion that can be acceptable for citizens is to be researched; moreover, an analysis of places that according to citizens' opinion might be crowded and should not be congested due to tourists under any condition should be conducted. Additionally, in-depth research of the perception of citizens of gentrification processes as well as changes in the real estate market are to be surveyed. All those analyses are extremely difficult, as particular cities and their inhabitants might differ significantly and research conducted in different places might lead to highly differentiated results. The example of Berlin can be presented here [49]. The city still struggles with underdeveloped residential infrastructure in the former communist part of the city and the negative influence of tourism development on the real estate market is experienced here especially severely. Similarly, local conditions, typical for a particular city, might play an important role in other cities as well. This differentiation of local conditions makes the impact of tourism and citizens' perceptions of the problem being highly differentiated between particular cities; moreover, solutions should rather be tailored than universal, suggested for each particular city. Understanding local conditions and factors influencing effectiveness of tourism policy in particular cities are then another important direction of future research.

However future research should not concentrate on destinations and their inhabitants only. In-depth studies are also required in the field of analysis of visitors to cities and their needs, requirements and behavior. This topic seems to be especially attractive for scientific research, as this group of tourists presents a mixture of features derived from different models of tourists' behavior. Following contemporary models of tourists (3Es), they are often active and open for contacts with the local people and the local real life and culture, exactly as, for many year, has been advocated for by supporters of alternative tourism and experience marketing. However, at the same time, they have often gained their tourism experiences during numerous stays in mass resort-like destinations (3Ss). During those stays, they used to be demanding customers and "consumers of destinations" that are completely tailored to their needs. In such a case, they simply do not ask local people if they are willing to have their everyday life be an attraction for tourists [49]. This misunderstanding between the expectations of 
hosts and guests is among the basic reasons for anti-tourism movements and tourism-phobia [49]. The divergence between citizens' and tourists' perceptions of their encounters is one of the most attractive topics for interdisciplinary research in the future as this topic includes issues typical for sociology, psychology, marketing, geography, urban studies and other scientific fields. Additionally, further analysis of how the description of tourists' motivations and behavior presented in contemporary tourism literature (especially according to the 3Es model) fits and reflects the situation observed in many cities should be conducted. Thus far, this issue was not raised in the tourism literature, and the description of its importance is intended to be among the most important contributions of the paper to the scientific knowledge.

Local authorities in many cities still attempt to use well-known strategies that have proved to be effective in resorts or nature-based destinations, as the scientific toolkit available for cities is almost empty. Filling this toolkit is an important task for scientists dealing with the topic. However, establishing new tools to be effective in contemporary tourism cities is not sufficient. Solving the problem of overtourism requires the creation of new bases of tourism policy adjusted for cities. It is not possible to solve the problem of overtourism in cities without a fundamental shift in the tourism policy and in the general perception of tourism as a phenomenon that is always wanted, invited and effective. However, based on several studies presented thus far, it is already possible to present a few practical recommendations for tourism decision-makers in cities. In the times of overtourism, even in the highly competitive global environment, building the tourist attractiveness of cities is not going to be the priority. It should rather be managed so as to make the level of tourism traffic satisfactory. This is a challenging task, as such a policy was not implemented widely in any city, and the theoretical background for such actions is missing as well. Thus far, tourism with its natural tendency to spread and "conquer" new territories was not perceived as a negative issue, as this was related to growing positive economic effects. On the contrary, in the literature on tourism development based on resorts-like destinations, local stakeholders' education was perceived as an important attitude to secure the local support for bigger and bigger growth of tourism [93-95]. Inhabitants who resist further tourism development should not be perceived as making a mistake anymore. This shift in tourism policy should be also reflected in marketing activities conducted by authorities of particular cities. This should embrace both different approaches to the continues growth of the number of visitors as well as the different perception of tourists' behavior. Tourists' behavior in accordance with the 3Es concept, which is enthusiastically welcomed in other destinations, causes additional problems in cities and creates even more tension between residents and tourists. The question about the selection of the desired market target and the way of communication with it is to be answered in particular cities as well as in scientific literature.

It seems that the development of overtourism should be perceived in a way described by Hall $[96,97]$ as a third-order change. Unlike the first-order change, which can be characterized by incremental, routinized, satisfactory behavior that leads to a change of the basic instruments of policy and to the second-order change which bring modification of the strategic behavior of authorities, the third-order change involves the shift in the whole policy paradigm [96-98]. Thus, the new goal hierarchy is adopted by policymakers because the coherence of the existing policy paradigm has been undermined. This occurs if a failure in the perceived policy results in discrepancies or inconsistencies that cannot be explained within the existing paradigm [98]. The overtourism creates such different conditions for the functioning of contemporary cities that without a paradigm shift and establishing a comprehensive attitude towards the problem, the policymakers may only react and minimize particular costs of the overtourism. Currently, there are no convincing examples of authorities that would take such an approach toward overtourism.

\subsection{Limitations}

Among important limitations of the argumentation presented, simplification of resorts-cities dichotomy is probably the most significant one. In fact, in reality, we can find plenty of examples that 
do not fit this dichotomy. Obvious examples are nature-based destinations related to lower intensity tourism such as ecotourism or agritourism. However, researchers are aware of them, and special requirements for strategies of tourism development for those destinations are well-recognized and often researched in the scientific literature, which makes the rules of their development commonly known and usually accepted. A much bigger problem is related to destinations that might be placed on the continuum between resorts and cities that cannot actually be labeled as any of them. These are often small cities that became economically dependent on tourism traffic. Examples of Dubrovnik [32] and Venice $[6,27,99]$ presented here, and also places such as Palma de Majorca [100], prove that the situation of those destinations is extremely complicated. In big cities that are not dependent on tourism, it is possible to keep only the supportive function of tourism in economic development while limitations for tourists, which may make them less attractive for them in favor of citizens' quality of life, can be introduced. This is not reasonable in those cities that may economically collapse without tourists' expenditures. However, many citizens there are not directly involved in tourism and as such do not perceive their prosperity as obtained from tourism. They suffer significantly from both the scale of tourism traffic and the behavior of particular tourists. The second issue seems to be an even more dramatic problem in places such as Palma de Majorca, which became typical 3S resorts, and participants of that kind of tourism tend to be particularly annoying for citizens. Finding a proper strategy for that kind of destination seems to be the most urgent and most challenging task for tourism academia and practitioners, as improving citizens' quality of life and maintaining a high level of income from tourism at the same time is extremely difficult, if possible. Still, Dubrovnik, Palma de Majorca or Venice should be perceived as urgent warnings for other cities not to follow their way and introduce some limits on tourism growth before they are stuck in a no-way-out situation.

Another important limitation of the paper presented and of wider suggested future development of the theory of the development of tourism in cities, is the fact that the problem of overtourism cannot be perceived as uniform in all cities. In fact, in many cities, the problem is not observed yet. Moreover, in cities where some symptoms of overtourism were detected, they often differ between one another in significant details. In such a case, it is difficult to create a universal theory that helps to solve many different problems. One more difficulty in creating a theory of tourism development in cities is the fact that tourism is neither easy to isolate from other development issues in a city, nor does such an action make any sense. There are so many aspects related to each other that discussing tourism development as an isolated issue is not a proper approach. Additionally, there are many issues that might be seen as not related to tourism in the city, but it may turn out that they actually are. The example of the new law proclaimed by local authorities in Berlin in October 2019 of freezing prices of long-term residential rental of houses and apartments can be presented here. The law was not intended to influence tourism traffic in the city. However, it may turn out that the growing difference in profitability of long-term rental and short-term tourism rental is going to be mirrored in more and more attempts to move real estates from the residential market into the tourism market, which will cause the number of real estates offered via Airbnb or similar platforms to grow, making shortages on the residential market even more painful.

Author Contributions: The author confirms sole responsibility for the following: study conception and design, data collection, analysis and interpretation of results, and manuscript preparation. All authors have read and agreed to the published version of the manuscript.

Funding: This research received no external funding

Conflicts of Interest: The authors declare no conflict of interest

\section{References}

1. Phi, G.T. Framing overtourism: A critical news media analysis. Curr. Issues Tour. 2019. [CrossRef]

2. Sinden, J.A. Carrying capacity as a planning concept for national parks: Available or desirable capacity. Land. Plan. 1975, 2, 243-247. [CrossRef] 
3. Kuss, F.R.; Morgan, J.M., III. Estimating the physical carrying capacity of recreation areas: A rationale for application of the universal soil loss equation. J. Soil Water Conserv. 1980, 35, 87-89.

4. Doxey, G. A causation theory of visitor-resident irritants: The impact of tourism. In Proceedings of the TTRA: The 6th Annual Conference, TTRA, San Diego, CA, USA, 23 September 1975; pp. 195-198.

5. Perkumienè, D.; Pranskūnienė, R. Overtourism: Between the right to travel and residents' rights. Sustainability 2019, 11, 2138. [CrossRef]

6. Capocchi, A.; Vallone, C.; Pierotti, M.; Amaduzzi, A. Overtourism: A literature review to assess implications and future perspectives. Sustainability 2019, 11, 3303. [CrossRef]

7. Milano, C.; Novelli, M.; Cheer, J.M. Overtourism and tourismphobia: A journey through four decades of tourism development, planning and local concerns. Tour. Plan. Dev. 2019. [CrossRef]

8. Higgins-Desbiolles, F.; Carnicelli, S.; Krolikowski, C.; Wijesinghe, G.; Boluk, K. Degrowing tourism: Rethinking tourism. J. Sustain. Tour. 2019, 27, 1926-1944. [CrossRef]

9. Alonso-Almeida, M.D.M.; Borrajo-Millán, F.; Yi, L. Are Social Media Data Pushing Overtourism? The Case of Barcelona and Chinese Tourists. Sustainability 2019, 11, 3356. [CrossRef]

10. Koens, K.; Postma, A.; Papp, B. Is Overtourism overused? understanding the impact of tourism in a city context. Sustainability 2018, 10, 4384. [CrossRef]

11. UNWTO. Overtourism? Understanding and Managing Urban Tourism Growth beyond Perceptions: Executive Summary; UNWTO: Madrid, Spain, 2018.

12. Peeters, P.M.; Gössling, S.; Klijs, J.; Milano, C.; Novelli, M.; Dijkmans, C.H.S.; Mitas, O. Research for TRAN Committee-Overtourism: Impact and Possible Policy Responses; European Parliament, Directorate General for Internal Policies, Policy Department B: Structural and Cohesion Policies, Transport and Tourism: Brussels, Belgium, 2018.

13. Goodwin, H. The Challenge of Overtourism; Working Paper 4; Responsible Tourism Partnership: Cape Town, South Africa, 2017.

14. Butler, R. Challenges and opportunities. World. Hosp. Tour. Them. 2018, 10, 635-641. [CrossRef]

15. Milano, C. Overtourism and Tourismphobia: Global Ttrends and Llocal Contexts; Ostelea School of Tourism and Hospitality: Barcelona, Spain, 2017.

16. Dodds, R.; Butler, R. (Eds.) Overtourism: Issues, Realities and Solutions; De Gruyter: Berlin, Germany, 2019.

17. Stanchev, R. The Most Affected European Destinations by Over-Tourism; Universitat de les Illes Beleares: Palma de Mallorca, Spain, 2018.

18. Namberger, P.; Jackisch, S.; Schmude, J.; Karl, M. Overcrowding, Overtourism and Local Level Disturbance: How Much Can Munich Handle? Tour. Plan. Dev. 2019, 16, 452-472. [CrossRef]

19. Gürsoy, İ.T. Beauty and the Beast: A Fairy Tale of Tourismphobia. Tour. Plan. Dev. 2019, 16, 434-451. [CrossRef]

20. Cazes, G.H. Alternative tourism: Reflections on an ambiguous concept. Europäische Hochschulschriften 1989, 10, 117-126.

21. Wheeller, B. Tourism's troubled times: Responsible tourism is not the answer. Tour. Manag. 1991, 12, 91-96. [CrossRef]

22. Whinney, C. Good Intentions in a Competitive Market: Training for People and Tourism in Fragile Environments. In People and Tourism in Fragile Environments; Price, M.F., Smith, V.L., Eds.; Oxford University: Oxford, UK, 1996; pp. 221-230.

23. MacCannell, D. Staged authenticity: Arrangements of social space in tourist settings. Am. J. Soc. 1973, 79, 589-603. [CrossRef]

24. MacCannell, D. The Tourist: A New Theory of the Leisure Class; Schoken Books: New York, NY, USA, 1976.

25. Martins, M.M. Tourism Planning and Tourismphobia: An Analysis of the Strategic Tourism Plan of Barcelona 2010-2015. J. Tour. Herit. Serv. Mark. 2018, 4, 3-7.

26. Trancoso González, A. Venice: The problem of overtourism and the impact of cruises. J. Reg. Res. 2018, 42, 35-51.

27. Seraphin, H.; Sheeran, P.; Pilato, M. Over-tourism and the fall of Venice as a destination. J. Destin. Mark. Manag. 2018, 9, 374-376. [CrossRef]

28. Cheer, J.M.; Milano, C.; Novelli, M. Afterword: Over Overtourism or Just the Beginning? In Overtourism: Excesses, Discontents and Measures in Travel and Tourism; Milano, C., Cheer, J.M., Novelli, M., Eds.; CABI: Wallingford, CT, USA, 2019; pp. 227-232. 
29. UNWTO. International Tourism Highlights, 2019 Edition; UNWTO: Madrid, Spain, 2019.

30. Hall, C.M. On the mobility of tourism mobilities. Curr. Issues Tour. 2015, 18, 7-10. [CrossRef]

31. Veiga, C.; Santos, M.C.; Águas, P.; Santos, J.A.C. Sustainability as a key driver to address challenges. World Hosp. Tour. Them. 2018, 10, 662-673. [CrossRef]

32. Panayiotopoulos, A.; Pisano, C. Overtourism dystopias and socialist utopias: Towards an urban armature for Dubrovnik. Tour. Plan. Dev. 2019, 16, 393-410. [CrossRef]

33. Pintassilgo, P.; Silva, J.A. 'Tragedy of the commons' in the tourism accommodation industry. Tour. Econ. 2007, 13, 209-224. [CrossRef]

34. Losada, N.; Alén, E.; Domínguez, T.; Nicolau, J.L. Travel frequency of seniors tourists. Tour. Man. 2016, 53, 88-95. [CrossRef]

35. Santos, A.; Cincera, M. Tourism demand, low cost carriers and European institutions: The case of Brussels. J. Transp. Geogr. 2018, 73, 163-171. [CrossRef]

36. Getz, D.; Page, S.J. Progress and prospects for event tourism research. Tour. Man. 2016, 52, 593-631. [CrossRef]

37. Horner, S.; Swarbrooke, J. Consumer Behaviour in Tourism, 3rd ed.; Routledge Taylor \& Francis Group: London, UK; New York, NY, USA, 2016.

38. Maitland, R. Introduction: National Capitals and City Tourism. In City Tourism: National Capital Perspectives; Maitland, R., Ritchie, B.W., Eds.; Cabi: Wallingford, CT, USA, 2009.

39. Pasquinelli, C.; Bellini, N. Global Context, Policies and Practices in Urban Tourism: An Introduction. In Tourism in the City. Towards an Integrative Agenda on Urban Tourism; Bellini, N., Pasquinelli, C., Eds.; Springer: Cham, Switzerland, 2017; pp. 1-25.

40. Andriotis, K. Integrated resort development: The case of Cavo Sidero, Crete. J. Sustain. Tour. 2008, 16, 428-444. [CrossRef]

41. Tham, A.; Huang, D. Game on! A new integrated resort business model. Tour. Rev. 2018. [CrossRef]

42. Wilkinson, P.F. Tourism in small island nations: A fragile dependence. Leis. Stud. 1987, 6, 127-146. [CrossRef]

43. Sheldon, P.J.; Var, T. Resident attitudes to tourism in North Wales. Tour. Man. 1984, 5, 40-47. [CrossRef]

44. Dwyer, L.; Kim, C. Destination competitiveness: Determinants and indicators. Curr. Issues Tour. 2003, 6, 369-414. [CrossRef]

45. Enright, M.J.; Newton, J. Determinants of tourism destination competitiveness in Asia Pacific: Comprehensiveness and universality. J. Travel Res. 2005, 43, 339-350. [CrossRef]

46. Buhalis, D. Marketing the competitive destination of the future. Tour. Man. 2000, 21, 97-116. [CrossRef]

47. Paskaleva-Shapira, K.A. New paradigms in city tourism management: Redefining destination promotion. J. Travel Res. 2007, 46, 108-114. [CrossRef]

48. García-Herrera, L.M.; Smith, N.; Mejías Vera, M.Á. Gentrification, displacement, and tourism in Santa Cruz de Tenerife. Urban Geogr. 2007, 28, 276-298. [CrossRef]

49. Füller, H.; Michel, B. 'Stop Being a Tourist!' New Dynamics of Urban Tourism in Berlin-Kreuzberg. Int. J. Urban Reg. Res. 2014, 38, 1304-1318. [CrossRef]

50. Di Natale, S.; Lewis, R.; Parker, R. Short-term rentals in small cities in Oregon: Impacts and regulations. Land Use Policy 2018, 79, 407-423. [CrossRef]

51. Wegmann, J.; Jiao, J. Taming Airbnb: Toward guiding principles for local regulation of urban vacation rentals based on empirical results from five US cities. Land Use Policy 2017, 69, 494-501. [CrossRef]

52. Palgan, Y.V.; Zvolska, L.; Mont, O. Sustainability framings of accommodation sharing. Environ. Innov. Soc. Trans. 2017, 23, 70-83. [CrossRef]

53. Boros, L.; Dudás, G.; Kovalcsik, T.; Papp, S.; Vida, G. Airbnb in Budapest: Analysing spatial patterns and room rates of hotels and peer-to-peer accommodations. Geoj. Tour. Geosites 2017, 21, 26-38.

54. Garcia-Ayllon, S. Urban Transformations as an Indicator of Unsustainability in the P2P Mass Tourism Phenomenon: The Airbnb Case in Spain through Three Case Studies. Sustainability 2018, 10, 8. [CrossRef]

55. del Romero Renau, L. Touristification, Sharing Economies and the New Geography of Urban Conflicts. Urban Sci. 2018, 2, 104. [CrossRef]

56. Horn, K.; Merante, M. Is home sharing driving up rents? Evidence from Airbnb in Boston. J. Hous. Econ. 2017, 38, 14-24. [CrossRef]

57. Dredge, D.; Gyimóthy, S.; Birkbak, A.; Elgaard Jensen, T.; Madsen, A. The Impact of Regulatory Approaches Targeting Collaborative Economy in the Tourism Accommodation Sector: Barcelona, Berlin, Amsterdam and Paris; Impact Paper No 9; Aalborg University: Aalborg, Denmark, 12 October 2016. 
58. Wachsmuth, D.; Weisler, A. Airbnb and the rent gap: Gentrification through the sharing economy. Environ. Plan. A Econ. Space 2018, 50, 1147-1170. [CrossRef]

59. Blanco-Romero, A.; Blázquez-Salom, M.; Cànoves, G. Barcelona, housing rent bubble in a tourist city. Social responses and local policies. Sustainability 2018, 10, 2043. [CrossRef]

60. The Guardian. Berlin's government legislates against Airbnb. 1 May 2016. Available online: https://www.theguardian.com/technology/2016/may/01/berlin-authorities-taking-stand-againstairbnb-rental-boom (accessed on 11 March 2019).

61. Rabadjieva, M. Terstriep, J. Micro-Entrepreneurship in the Sharing Economy-New Labour Market Opportunities. In Entrepreneurship and Entrepreneurial Skills in Europe; David, A., Hamburg, I., Eds.; Barbara Budrich: Leverkusen, Germany, 2017.

62. Vlahov, A.; Mustapić, M. Integrated hotels-Opportunity for raising competitiveness of private accommodation sector in Croatia. In Proceedings of the TOURMAN 2018 Conference, Rhodes, Greece, 25-28 October 2018; pp. 84-89.

63. Coyle, D.; Yu-Cheong Yeung, T. Understanding AirBnB in Fourteen European Cities; The Jean-Jacques Laffont Digital Chair: Toulouse, France, 2016.

64. Gurran, N.; Phibbst, P. When tourists move in. How should urban planners respond to Airbnb? J. Am. Plan. Assoc. 2017, 83, 80-93. [CrossRef]

65. Ključnikov, A.; Krajčík, V.; Vincúrová, Z. International sharing economy: The case of AirBnB in the Czech Republic. Econ. Sociol. 2018, 11, 126-137. [CrossRef]

66. Cocola-Gant, A. Tourism gentrification. In Handbook of Gentrification Studies; Lees, L., Phillips, M., Eds.; Edward Elgar Publishing: Cheltenham, UK; Northampton, UK, 2018.

67. Gotham, K.F. Tourism gentrification: The case of new Orleans' Vieux Carre (French Quarter). Urban Stud. 2005, 42, 1099-1121. [CrossRef]

68. Colomb, C.; Novy, J. Urban Tourism and its Discontents: An Introduction. In Protest and Resistance in the Tourist City; Colomb, C., Novy, J., Eds.; Routledge: London, UK, 2016; pp. 1-30.

69. Gladstone, D.; Préau, J. Gentrification in tourist cities: Evidence from New Orleans before and after Hurricane Katrina. Hous. Policy Debate 2008, 19, 137-175. [CrossRef]

70. Dumbrovská, V.; Fialová, D. Tourist intensity in capital cities in Central Europe: Comparative analysis of tourism in Prague, Vienna and Budapest. Czech J. Tour. 2014, 3, 5-26. [CrossRef]

71. Dumbrovská, V. Urban tourism development in Prague: From tourist mecca to tourist ghetto. In Tourism in the City. Towards an Integrative Agenda on Urban Tourism; Bellini, N., Pasquinelli, C., Eds.; Springer: Cham, Switzerland, 2017; pp. 275-283.

72. Smith, M.K.; Sziva, I.P.; Olt, G. Overtourism and resident resistance in Budapest. Tour. Plan. Dev. 2019, 16, 376-392. [CrossRef]

73. Milano, C.; Cheer, J.M.; Novelli, M. Introduction. In Overtourism: Excesses, Discontents and Measures in Travel and Tourism; Milano, C., Cheer, J.M., Novelli, M., Eds.; CABI: Wallingford, CT, USA, 2019.

74. Tosun, C. Challenges of sustainable tourism development in the developing world: The case of Turkey. Tour. Manag. 2001, 22, 289-303. [CrossRef]

75. Gouvea, R. Managing the ecotourism industry in Latin America: Challenges and opportunities. Probl. Persp. Manag. 2004, 2, 71-79.

76. Benner, M. From Overtourism to Sustainability: A research Agenda for Qualitative Tourism Development in the Adriatic; MPRA Paper No 92213; Heidelberg University: Heildelberg, Germany, 2019. Available online: https://mpra.ub.unimuenchen.de/92213/ (accessed on 10 April 2019).

77. Butler, R.W. Alternative tourism: Pious hope or Trojan horse? J. Travel Res. 1990, 28, 40-45. [CrossRef]

78. Cohen, E. “Alternative Tourism"-A Critique. Tour. Recreat. Res. 1987, 12, 13-18. [CrossRef]

79. Mohamad, N.H.; Razzaq, A.R.A.; Khalifah, Z.; Hamzah, A. Staged Authenticity: Lessons from Saung Anklung Udjo, Bandung, Indonesia. J. Tour. Hosp. Cult. Arts 2011, 24, 43-51.

80. Cohen, E. Authenticity and commoditization in tourism. Ann. Tour. Res. 1988, 15, 371-386. [CrossRef]

81. Apollo, M.; Rettinger, R. Mountaineering in Cuba: Improvement of true accessibility as an opportunity for regional development of communities outside the tourism enclaves. Curr. Issues Tour. 2019, 22, 1797-1804. [CrossRef]

82. Gračan, D.; Zadel, Z.; Rudančic-Lugaric, A. Strategic management of cultural-tourism resources. Acad. Tur. Tour. Innov. J. 2010, 3, 16-25. 
83. Antczak, B. The role of tourism in European Union-Selected issues. J. Mod. Sci. 2018, 38, 41-52.

84. Kowalczyk, A. The phenomenology of tourism space. Turyzm 2014, 24, 9-15. [CrossRef]

85. Pine, B.J.; Gilmore, J.H. The Experience Economy: Work is the Theatre and Every Business is a Stage; HBS Press: Boston, MA, USA, 1999.

86. Hirschman, E.C.; Holbrook, M.B. Hedonic consumption: Emerging concepts, methods and propositions. J. Mark. 1982, 46, 92-101. [CrossRef]

87. Holbrook, M.B.; Hirschman, E.C. The experiential aspects of consumption: Consumer fantasies, feelings, and fun. J. Consum. Res. 1982, 9, 132-140. [CrossRef]

88. Frochot, I.; Batat, W. Marketing and Designing the Tourist Experience; Goodfellows: Oxford, UK, 2013.

89. Uriely, N. The tourist experience: Conceptual developments. Ann. Tour. Res. 2005, 32, 199-216. [CrossRef]

90. Costa, C.; Peres, R.; Moital, M. Lisbon as a city break destination: A competitive analysis as perceived by London travel agents. J. Tour. Dev. 2005, 2, 67-80.

91. Dunn, G.; Buckley, J.; Flanagan, S. City Break Travel Motivation-The Case of Dublin. J. Travel Tour. Res. 2007, 22, 95-107. [CrossRef]

92. Hyde, K.; Decrop, A.; Dunne, G.; Flanagan, S.; Buckley, J. Towards a decision making model for city break travel. Int. J. Cult. Tour. Hosp. Res. 2011, 5, 158-172.

93. Kiper, T.; Özdemir, G.; Saglam, C. Enviromental, socio-cultural and economical effects of ecotourism perceived by the local people in the northwestern Turkey: Kiyiköy case. Sci. Res. Essays 2011, 6, 4009-4020.

94. Kwilecki, K. Analysis and Assesment of Lubuskie Province in Terms of Tourism Development. Sci. J. Serv. Manag. 2014, 14, 49-57.

95. Pásková, M.; Zelenka, J.; Pásková, M.; Zelenka, J. Sustainability Management of Unesco Global Geoparks. Sustain. Geosci. Geotour. 2018, 2, 44-64. [CrossRef]

96. Hall, C.M. Tourism and Politics: Policy, Power, and Place; John Wiley: Chichester, UK, 1994.

97. Hall, M.C. Policy learning and policy failure in sustainable tourism governance: From first- and second-order to third-order change? J. Sustain. Tour. 2011, 19, 649-671. [CrossRef]

98. Greener, I. Social learning and macroeconomic policy in Britain. J. Public Policy 2001, 21, 133-152. [CrossRef]

99. Minoia, P. Venice reshaped? Tourist gentrification and sense of place. In Tourism in the City. Towards an Integrative Agenda on Urban Tourism; Bellini, N., Pasquinelli, C., Eds.; Springer: Cham, Switzerland, 2017; pp. 261-272.

100. Colom-Montero, G. Mass tourism as cultural trauma: An analysis of the Majorcan comics Els darrers dies de 1'Imperi Mallorquí (2014) and Un infern a Mallorca (La decadència de l'Imperi Mallorquí) (2018). Stud. Comics 2014, 10, 49-71. [CrossRef] 